\title{
Challenging the nice girl
}

\author{
Louise Nealon
}

(C) Louise Nealon. This work is licensed under the Creative Commons Attribution-NonCommercialNoDerivatives 4.0 International License. To view a copy of this license, visit http://creativecommons.org/licenses/by-nc-nd/4.0/.

Louise Nealon is a writer from county Kildare. She plays corner back for her local camogie club, Cappagh GAA. This piece based on a presentation given at a conference entitled, Sidelines, Touchlines and Hemlines: Irish Women in Sport, in Dundalk County Museum on February 2020.

Keywords: Camogie (Game); Ireland; Competitiveness (Psychology)

I want to give up playing camogie again. We had a challenge match yesterday against a younger team that play in a division above us. They hammered us. I was keeled over and hyperventilating for most of the match, and embarrassingly enough, I began to cry. I managed to hide my whingeing until the match was over, and I had to take off my helmet. The others started cooling down and stretching. I couldn't pass the tears off as sweat anymore, so I disappeared off to sit in the car.

I didn't know why I was crying. I knew that I was angry. I was angry at the spiteful teenager I was marking who kept holding my hurl. I was angry at the truck of the girl who bulldozed her way into our goalie, Hazel, whose entire body is held together by tape and determination. A tiny bit of me might have been angry that we lost the match too. I'm angry that we're vulnerable and messy and human.

The referee spent the entire game laughing at these silly girls with sticks being overly emotional. He came over to us after the game was over and, with a paternal wink, told us we better pull our socks up. He put his hand on the shoulder of our new trainer and said, 'If there's anyone I know who can whip a team into shape, it's this man here'. So I was angry with the referee too, for implying that the only way we could improve as a team was to listen to and obey orders from a man. I was angry that if I pointed this out to my sister in the car journey home, she would have rolled her eyes and thought I was being ridiculous.

I have shed a lot of tears over camogie. I wouldn't cry so much if I stayed at home and did yoga and went for solo jogs down empty country roads. But I also know that if my little sister didn't drag me out of bed to hit a ball around with a stick on Saturday mornings, I wouldn't be in the position I am today. As well as being an overemotional corner-back, I am a writer. It is significant that for a long time, the only paid gigs I came by as an emerging writer were to discuss women in sport. A lot of this is down to the good fortune of knowing Eimear Ryan, a fellow writer and inter-county camogie player, who is kind enough to recommend me for gigs when she can't do them herself, mostly because they clash with camogie training. It is thanks to Eimear that I have tumbled into thinking about women in sport. 
My mother was baffled when I told her that Darren Frehill - RTE sport commentator and man most likely to be heard through our kitchen radio speakers - got in touch with me about doing a sports panel discussion for Culture Night 2018.

'Are you sure he had the right number love?' she frowned.

'Yeah Mam', I sighed.

'Yeah, but love - and I mean this in the best way - you are not an athlete. And, to be honest, I didn't know you even liked sport'.

My mother understands the irony of me representing my entire gender in a panel discussion about sport. I wouldn't list sport as one of my interests on a dating site. I'm not very into it at all. I have found myself being the token woman on a panel of men discussing sport, often on national airwaves. Sometimes I feel like an absolute fraud.

We live in an apologetic society - a society that recognises that it has failed to accommodate or recognise female experiences in the past and is trying to make up for their mistakes. And so, the patriarchal system behaves like a clumsy lover who begs to be taken back. It is over-polite to women. Men want to know what they can do to level the playing field for us. They expect us to come up with comprehensive answers to their questions. But we are used to playing uphill. Women are just as confused as men about how to move forward in a society that recognises it is flawed, but does not know the best way to proceed. And that's the reason why someone like me is invited onto a panel show, not to talk about sport exactly, but to talk about my gender's relationship to sport. It is the reason I am writing this essay.

There is a photo of our camogie team after winning the Intermediate final last year. There are about thirty of us in red and white striped jerseys like a Where's Wally? drawing, posing on top of, or next to, a battered Renault Mégane. The Cappagh car's battery died on our victory lap down the hill into the village after we won the Intermediate Kildare County Championship by a point. After the Cappagh car conked out, it was towed to its final resting place outside our local pub where the celebrations commenced.

A year before we won the championship, I was very reluctant to go back to camogie training. Like a lot of Irish people, I have a complicated relationship with the GAA. My family name is synonymous with our local club, so when I was growing up, I never really had a choice when it came to playing camogie. I became an aunt for the first time a few months ago, and one of the first gifts that my little niece, Sophie, received when she was born was a tiny hurly with her name engraved on it along with her date of birth. My father is still raging that Sophie was born in December, which isn't great when it comes to qualifying for underage teams.

Even though I don't come from a hurling county or play for a well-known team, I grew up with a hurl in my hand. I was one of the good players in underage, but as we got older, I fell behind my teammates. I wasn't as committed as some of them. I didn't have as much natural skill. I was being put in the corner instead of midfield. Then I failed to make the starting team. I wasn't good enough to make the first fifteen. So eventually, I stopped playing.

When I was in my late teens and early twenties, I prided myself on being a perfectionist. I got straight As in my Leaving Cert. When I went to college, I struggled to get good results. I spent all of my time in the library. I was miserable. I was lonely, but I was still holding onto my values. I wasn't perfect, but at least I was trying. I couldn't imagine ever being kind to myself. I thought that if I said something positive about myself, that meant that I was full of myself.

Des Bishop talks about the way the Irish treat successful people - people who are doing well for themselves. Look at yer man over there. Doesn't he love himself? God forbid loving 
yourself. There's a lot of that in the Irish psyche. Don't get above your station. Make sure to take yourself down a peg or two by giving out to yourself. I've grown up thinking it's normal to be hard on myself. I thought that was the only way I'd become a better person.

I wore my perfectionism as a badge of honor until my local GP said that he thought perfectionism was a kind of neurosis. I remember being baffled when he suggested that in order to function, I needed to start being kinder to myself.

I was diagnosed with depression and anxiety when I was twenty-one. I am on medication, and I have been lucky enough to go to therapy. My family have been an incredible support to me. We have all learned a lot. I have been learning to manage my mental illness for a while now. There is no fixed cure for treating depression. Depression burrows right into the core of who you really are. It takes a long time to treat and requires a lot of patience and trust, both from the person themselves and the people around them. However, when you begin to heal, the change is profound.

While playing team sport can work wonders for some people's mental health, for others, it can exacerbate it. I always thought that I was in the latter camp. My sister Catherine was always on at me to go back to camogie because it brings her so much joy. I couldn't really explain to her why I wouldn't go back. The reason I stopped playing camogie in the first place was because I couldn't cope with failure. I couldn't handle the emotional pressure of being part of a team - that shared feeling of disappointment after we had a bad game, or the frustration when we knew we weren't playing to the best of our potential. I used to cry after training and obsess over the things I did wrong. I used to constantly give out to myself.

So when I agreed to go back to camogie, I knew that I had to approach playing in a different way. When I was running in drills I'd tell myself, 'God you're going well, keep going. Good woman yourself. You can go a bit faster now'. And that rewired my brain. When I gave out to myself, I froze on the pitch. I didn't play well. I knew that if I kept on ruminating about all of the things I did wrong, I wasn't going to play well. I went through a couple of mental stumbling blocks. I tried to think positively and ended up annoying myself even more. Then I attempted to train myself not to think negatively. Then I realised, the trick was to try not to think at all. I focused on the ball. On the present moment. And that was a kind of meditation.

In her book, Flourishing, Maureen Gaffney says that for every negative thought, we need five positive thoughts to balance the equilibrium. The magic ratio of maintaining a neutral state of mind is five positive thoughts to one negative thought. Negative thoughts are so much more powerful than positive thoughts.

I remember a psychotherapist asking me to describe five negative qualities about myself, and I had a list the length of my arm. She asked me to describe five positive qualities about myself, and I burst out crying because I couldn't think of one.

So now, after every camogie match, I list five things that I did well during the match and five things that I could improve on. And I really make myself focus on both - reflect on both for an equal amount of time. It's so easy to discount the positive.

My teammates are able to catch me out when I start to be hard on myself. We encourage each other. We have the craic, but we also take each other seriously. Nobody around us takes playing for a local camogie team as seriously as we do. Cappagh means so much more to us than we could ever explain. For us, club is family.

Like all families, we have our ups and downs, on and off the pitch. One of the girls on the team lost her husband not so long ago. They were newly married and she was pregnant at the time. A few months later, she had a beautiful baby boy. She went back training camogie 
and was our captain the day we won the county final. All of us were crying when she lifted the cup. Another one of my teammates lost her three-year-old daughter. I will never forget going to that funeral and seeing the tiniest white coffin on the altar with a Peppa Pig ballon tied to one its golden handles. We wore our jerseys to the funeral and made a guard of honour.

Ask any manager that Cappagh Camogie has ever had and they will probably say the same thing. We're nice girls. We are a hard working team. We're not afraid to put in the donkey work at training, but we are nearly too polite to go out and actually win a match. Sure that would only be rude. The other team would be upset. And us? Well, we're used to it. Most of us have been playing since we were old enough to carry a hurl - tiny things running around the pitch with helmets that made us look like bobble heads. We were acquainted with losing from an early age. The other teams used to call us Crappagh.

We were content with this assessment of our team, until we met with a trainer who revolutionised the way we thought about sport and the way we thought about ourselves. One of the first things I learned about Niall Williams was that he was a fan of Beyoncé. He was giving a pre-match prep talk when his phone rang, and the Single Ladies ringtone blasted out of his pocket. We all laughed, glad that the tension had been broken, because frankly, we thought he was expecting too much from us. He was a Cappagh manager now. He needed to learn how to lose.

Niall silenced Beyoncé, turned off his phone and said, 'Listen, you're a great bunch of people, but ye need to start believing you can go out there and compete. Ye want to play the nice girls? That's grand. But remember that nice girls don't win championship. Nice girls win the Rose of Tralee'.

As the camogie season went on, we stopped trying to live up to the aesthetic of the nice girl. Every time the ref threw in the ball to start a match, we stopped behaving like nice girls. When we rocked up to training, we made sure that we left our nice girl personas in the dressing room. Instead, we learned that we could be brave, aggressive, competitive, determined and focused. We could also be petty, immature and downright psychotic. We were given the freedom to express the best and worst parts of ourselves. To this day, whenever I pick up a hurl and puck a ball around, I feel like I've broken through the fetters of gender into a space that is boundless and free. I'm no longer girl or even woman. I'm human. And sometimes, I feel superhuman. I am capable of doing things I never thought I could do.

Out of a panel of twenty-seven women, eleven of my fellow teammates are mothers, with eighteen children between them. On my first session back training, I ended up marking my old baby-sitter. She roasted me, and she was breastfeeding her third child at the time. She has become my image of an inspirational athlete.

Sometimes, I want to give up playing camogie. Every so often, I crawl back into my default mode of being a nice girl who is afraid to step outside her comfort zone. Playing camogie for Cappagh is my way of dealing with the perfectionist inside me who is paralysed by anxiety and fear of failure. It's so much safer to watch from the sidelines. But then I look at my teammates sweating, panting, breaking limbs and pulling muscles, and I want to be out there, in the mix, even though it's hard and sometimes heartbreaking. I want to have a messy, busy life full of challenge. I want to be breastfeeding my third child and still running rings around a young one in years to come. I want to be tested. I want to see what I'm made of.

Eimear Ryan, inter-county camogie player, writer and a good friend of mine, says that,

Hurling is often characterized as a warrior sport, a manly sport, full of aggression, competition, physicality and courage. And yet I see my teammates display these traits every time we go out to play, which makes me question if these are really masculine traits or just human traits. 
Playing sport has taught me that sometimes, the best way to feel human is to challenge the nice girl that everyone else expects me to be. I am part of Cappagh Camogie and we are not perfect by any means. Playing alongside these women makes me feel very alive, and very human. 